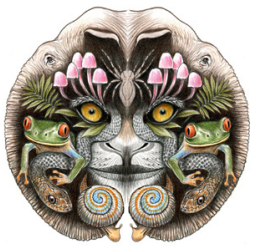

ISSN 0974-7907 (Online) ISSN 0974-7893 (Print)

\section{OPEN ACCESS}

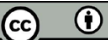

\title{
KNOWN FROM A HANDFUL OF SPECIMENS: ANALYZING THE WORLDWIDE PATTERNS OF OCCURRENCE AND CONSERVATION OF RODENTS AND SHREWS RECORDED ONLY FROM THE TYPE LOCALITY
}

\author{
Giovanni Amori ${ }^{1}$, Guido Alari Esposito ${ }^{2}$ \& Luca Luiselli ${ }^{3}$
}

${ }^{1,2}$ CNR - Institute for Ecosystem Study, Piazzale Aldo Moro, 7 - 00185, Rome, Italy ${ }^{3}$ Niger Delta Ecology and Biodiversity Conservation Unit, Department of Applied and Environmental Biology, Rivers State University of Science and Technology, PMB 5080, Port Harcourt, Rivers State, Nigeria ${ }^{1}$ giovanni.amori@uniroma1.it (corresponding author), ${ }^{2}$ al.gu@hotmail.it, ${ }^{3}$ lucamlu@tin.it

\begin{abstract}
Traditionally, conservation research has not focused on Rodentia and Soricomorpha, and many species are known from a handful of specimens and the type locality only (few and type locality species (FETP)). Here we studied the patterns of occurrence of FETP rodents and soricomorphs in relation to geographical area and vegetation zones and report some conservation considerations. Overall, 91 species of Rodentia and 19 species of Soricomorpha were selected. There was a positive correlation between number of species per genus and number of FETP species in each genus. The majority of FETP rodents occur in the Neotropical, Afrotropical and Oriental regions, and soricomorphs in the Afrotropical and Oriental regions. Higher numbers of FETP rodent species occurred in Argentina and Indonesia. There was a positive relationship between species richness of rodents per country and number of FETP species. In terms of habitat type, FETP species of rodents and soricomorphs showed similar patterns, with most species being found in rainforest. The great majority of selected species of both groups were Data Deficient (DD), with Critically Endangered (CR) accounting for $16.5 \%$ of Rodentia and $5.3 \%$ of Soricomorpha. Overall, IUCN threatened species mostly occur in the Neotropical region, followed by the Afrotropical region. It is urged that IUCN authorities should promptly revise all FETP species and their precautionary CR status, at least when a reasonable timespan (i.e., $>25$ years) has passed since the last records.
\end{abstract}

Keywords: Ecological patterns, small mammals, rare species, type locality.

Riassunto: Tradizionalmente, la ricerca sulla biologia della conservazione non si è concentrata sui Rodentia e Soricomorpha, e molte specie sono note da pochi esemplari rinvenuti esclusivamente nella località tipo (specie 'FETP' nel presente articolo). In questo lavoro, sono stati studiati i modelli di occorrenza di roditori e soricomorfi FETP in relazione alle regioni zoogeografiche e ai tipi di vegetazione. Inoltre, vengono riportate alcune considerazioni di conservazione. Nel complesso, sono state selezionate 91 specie di Rodentia e 19 specie di Soricomorpha. E' risultata una correlazione positiva tra il numero di specie per genere e numero di specie FETP all'inerno di ogni genere. La maggior parte dei roditori FETP si trovano nelle regioni neotropicale, afrotropicale e orientale, mentre la maggiore concentrazione di Soricomorpha FETP nelle regioni afrotropicale e orientale. II maggior numero di specie di roditori FETP è stato rinvenuto in Argentina e Indonesia. E' stata osservata una relazione positiva tra ricchezza di specie di roditori per paese e numero di specie FETP. Per quanto concerne il tipo di habitat, le specie FETP di roditori e di soricomorfi hanno mostrato modelli simili, con la maggior parte delle specie riscontrate in foresta pluviale. La grande maggioranza delle specie selezionate di entrambi i gruppi sono risultate, secondo la lista rossa UICN, come DD, mentre le specie CR hanno rappresentato il 16,5\% dei Rodentia e 5,3\% dei Soricomorpha. Nel complesso, le specie minacciate sono concentrate soprattutto nella regione neotropicale, seguita dalla regione Afrotropicale. Si suggerisce che le autorità dell'IUCN dovrebbero rivedere lo status di tutte le specie FETP e attribuire loro, in via precauzionale, lo status di CR, almeno quando un periodo ragionevole di tempo (cioè > 25 anni) è passato dagli ultimi record attendibili.

DOI: http://dx.doi.org/10.11609/jott.2405.8.3.8556-8563 | ZooBank: urn:Isid:zoobank.org:pub:11E66E4F-20D1-41E8-88F4-D8E3B96EF66E

Editor: Rainer Hutterer, Zoological Research Museum Alexander Koenig, Bonn, Germany.

Date of publication: 26 March 2016 (online \& print)

Manuscript details: Ms \# 2405 | Received 08 November 2015 | Final received 20 January 2016 | Finally accepted 29 February 2016

Citation: Amori, G., G.A. Esposito \& L. Luiselli (2016). Known from a handful of specimens: analyzing the worldwide patterns of occurrence and conservation of rodents and shrews recorded only from the type locality. Journal of Threatened Taxa 8(3): 8556-8563; http://dx.doi.org/10.11609/jott.2405.8.3.8556-8563

Copyright: (c) Amori et al. 2016. Creative Commons Attribution 4.0 International License. JoTT allows unrestricted use of this article in any medium, reproduction and distribution by providing adequate credit to the authors and the source of publication.

Funding: None.

Conflict of Interest: The authors declare no competing interests.

Author Details: GIOVANNI AMORI is a professor of zoology and works at the National Council of Research and is a leading expert of small mammal ecology, conservation and evolution. GUIDO ALARI ESPOSITO is a master student in biology at the Sapienza University of Rome and is interested in the mammal conservation. LUCA LUISELLI is a professor of ecology and works at the IDECC and at the Rivers State University of Science and Technology, Port Harcourt (Nigeria) and is a tropical ecologist and conservation biologist.

Author Contribution: GA and LL designed the study and wrote the article; GAE produced the dataset; all authors reviewed the article

Acknowledgements: We are indebted to Dr Giuliano Milana for having drafted the figures. 


\section{INTRODUCTION}

Narrow distribution ranges and small/restricted populations are key elements of extinction risk (e.g., Gaston 1994), with species having restricted distributions and low population sizes being at greatest immediate risk of extinction. Some taxa are known only from a handful of individuals and may be functionally analogous to 'singletons' in ecological communities (Gaston 1994). As with singletons these species are still largely unknown, and it is open to debate whether face a high risk of extinction or their rarity is a collection artefact.

The orders Rodentia and Soricomorpha include about $50 \%$ of mammal species, with 2,705 species out of a total of 5,416 (Wilson \& Reeder 2005). They inhabit almost every habitat and terrestrial and freshwater niche available, including flying species (Churchfield 1990; Hafner et al. 1998; Nowak 1999), and also play a key role in natural ecosystems (Golley et al. 1975; Carpaneto et al. 2011). Traditionally, conservation research and applications have been focused on large mammals (Amori \& Gippoliti 2000; Amori et al. 2011a, 2011b), despite the fact that many small mammal species are known from a handful of specimens. Some have been suspected to be extinct, with novel specimens not having been found for several decades (e.g., the Togo Mouse Leimacomys buettneri, see Schlitter 1989; Wilson \& Reeder 2005), although some have been recently rediscovered (e.g., Řeháková et al. 2015). This study highlights the distribution patterns, main habitats and conservation implications of the rarest/most neglected species of Rodentia and Soricomorpha, known only from their type locality and less than 10 individuals (hereby FETP species).

\section{MATERIALS AND METHODS}

In this paper we considered species of Rodentia and Soricomorpha fulfilling two concurrent criteria:

(i) being known just from the type locality;

(ii) being known from $<10$ individuals.

Species fulfilling these criteria are defined as FETP species. The list of FETP species was obtained using Wilson \& Reeder (2005). Distribution, habitat and conservation status were obtained from the IUCN database available at www.iucnredlist.org (accessed on 15 August 2015). For each FETP species we also recorded the corresponding biogeographical region. We excluded from analysis: (i) species known from few individuals that were recorded from distinct areas. For example instance the rodent Sigmodontomys aphrastus, is known from only seven specimens originating from widely separated locations in Costa Rica, Panama and the western slope of Ecuador (McCain et al. 2007)

(ii) species described after 2005 (e.g., Fukomys ilariae Gippoliti \& Amori 2011), on the assumption that additional individuals of recently-described species may be found in the future field surveys.

The following main habitat categories were considered for the analyses: (i) rainforest, (ii) wetlands, (iii) scrublands, (iv) grassland, (v) desert, (vi) temperate forest, (vii) urban, (viii) unknown.

Differences in the frequencies of species belonging to the various IUCN Red List categories between Rodentia and Soricomorpha were assessed by $\chi^{2}$ test. The correlation between number of rodent species per country and number of FETP species was run by Pearson's correlation coefficient, and the same analysis was also performed to explore the correlation between number of species of each genus and number of FETP species per genus. Data were log-transformed to achieve normality when necessary, prior to apply any parametric tests. All analyses were performed by PAST 3.0 statistical software.

\section{RESULTS}

The list of FETP species for both Rodentia and Soricomorpha is given in Table 1. Overall, 91 species of Rodentia and 19 species of Soricomorpha fulfilled the inclusion criteria of our study. The number of species per genus was positively correlated with the number of FETP species in each genus $\left(r=0.436, r^{2}=0.190, P<\right.$ 0.001; Fig. 1).

Concerning rodents, the majority of selected species occur in the Neotropical, Afrotropical and Oriental regions, whereas for soricomorphs in the Afrotropical and Oriental regions (Fig. 2). Looking at the country of origin, we observed that a high number of FETP species occurred in Argentina and Indonesia for rodents, whereas no country emerged as for the soricomorphs (Table 2). Overall, there was a significantly positive relationship between species richness of rodents per country and number of FETP species $\left(r=0.540, r^{2}=\right.$ 0.292 , $P<0.01$; Fig. 3). Thus, the high number of FETP species in Argentina and Indonesia merely depended on a overall high number of rodent species in these countries. 
Table 1. List of FETP species of Rodentia and Soricomorpha.

\begin{tabular}{|c|c|c|c|c|c|}
\hline Family & Species & Biogeographical region & Habitat & Country & IUCN status \\
\hline \multicolumn{6}{|l|}{ Rodentia } \\
\hline Abrocomidae & Abrocoma boliviensis & Neotropical & rainforest & Bolivia & CR \\
\hline Abrocomidae & Abrocoma shistacea & Neotropical & grasslands & Argentina & DD \\
\hline Abrocomidae & Abrocoma uspallata & Neotropical & desert & Argentina & DD \\
\hline Abrocomidae & Abrocoma vaccarum & Neotropical & scrublands & Argentina & DD \\
\hline Abrocomidae & Cuscomys ashaninka & Neotropical & rainforest & Peru & DD \\
\hline Capromyidae & Mesocapromys sanfelipensis & Neotropical & rainforest & Cuba & CR \\
\hline Capromyidae & Mysateles garridoi & Neotropical & rainforest & Cuba & CR \\
\hline Cricetidae & Akodon aliquantulus & Neotropical & grasslands & Argentina & DD \\
\hline Cricetidae & Akodon oenos & Neotropical & desert & Argentina & DD \\
\hline Cricetidae & Brucepattersonius albinasus & Neotropical & unknown & Brazil & DD \\
\hline Cricetidae & Brucepattersonius guarani & Neotropical & rainforest & Argentina & DD \\
\hline Cricetidae & Brucepattersonius igniventris & Neotropical & rainforest & Brazil & DD \\
\hline Cricetidae & Brucepattersonius misionensis & Neotropical & unknown & Argentina & DD \\
\hline Cricetidae & Brucepattersonius paradisus & Neotropical & rainforest & Argentina & DD \\
\hline Cricetidae & Euneomys fossor & Neotropical & grasslands & Argentina & DD \\
\hline Cricetidae & Graomys edithae & Neotropical & grasslands & Argentina & DD \\
\hline Cricetidae & Habromys delicatulus & Neotropical & rainforest & Mexico & CR \\
\hline Cricetidae & Juscelinomys guaporensis & Neotropical & grasslands & Bolivia & $\mathrm{DD}$ \\
\hline Cricetidae & Juscelinomys huanchacae & Neotropical & grasslands & Bolivia & $\mathrm{DD}$ \\
\hline Cricetidae & Microtus irani & Palearctic & urban & Iran & DD \\
\hline Cricetidae & Neotoma bryanti & Neotropical & scrublands & Mexico & EN \\
\hline Cricetidae & Neotoma nelsoni & Neotropical & rainforest & Mexico & CR \\
\hline Cricetidae & Oecomys cleberi & Neotropical & rainforest & Brazil & DD \\
\hline Cricetidae & Oxymycterus hucucha & Neotropical & rainforest & Bolivia & EN \\
\hline Cricetidae & Peromyscus mayensis & Neotropical & rainforest & Guatemala & CR \\
\hline Cricetidae & Rhipidomys ochrogaster & Neotropical & rainforest & Peru & DD \\
\hline Cricetidae & Thomasomys apeco & Neotropical & rainforest & Peru & VU \\
\hline Cricetidae & Thomasomys hudsoni & Neotropical & unknown & Ecuador & DD \\
\hline Cricetidae & Tylomys bullaris & Neotropical & rainforest & Mexico & $\mathrm{CR}$ \\
\hline Ctenomyidae & Ctenomys coludo & Neotropical & unknown & Argentina & DD \\
\hline Ctenomyidae & Ctenomys fodax & Neotropical & unknown & Argentina & DD \\
\hline Ctenomyidae & Ctenomys johannis & Neotropical & unknown & Argentina & DD \\
\hline Ctenomyidae & Ctenomys juris & Neotropical & unknown & Argentina & DD \\
\hline Echimyidae & Phyllomys unicolor & Neotropical & rainforest & Brazil & CR \\
\hline Echimyidae & Santamartamys rufodorsalis & Neotropical & rainforest & Colombia & $\mathrm{CR}$ \\
\hline Geomyidae & Orthogeomys lanius & Neotropical & rainforest & Mexico & CR \\
\hline Gliridae & Chaetocauda sichuanensis & Oriental & $\begin{array}{l}\text { temperate } \\
\text { forest }\end{array}$ & China & DD \\
\hline Muridae & Archboldomys musseri & Oriental & rainforest & Philippines & LC \\
\hline Muridae & Batomys dentatus & Oriental & rainforest & Philippines & $\mathrm{DD}$ \\
\hline Muridae & Carpomys melanurus & Oriental & rainforest & Philippines & DD \\
\hline Muridae & Crunomys fallax & Oriental & rainforest & Philippines & DD \\
\hline Muridae & Crunomys suncoides & Oriental & rainforest & Philippines & DD \\
\hline Muridae & Dipodillus lowei & Afrotropical & rainforest & Sudan & DD \\
\hline
\end{tabular}




\begin{tabular}{|c|c|c|c|c|c|}
\hline Family & Species & Biogeographical region & Habitat & Country & IUCN status \\
\hline Muridae & Gerbillus burtoni & Afrotropical & unknown & Sudan & DD \\
\hline Muridae & Gerbillus grobbeni & Afrotropical & desert & Libya & $\mathrm{DD}$ \\
\hline Muridae & Gerbillus principulus & Afrotropical & scrublands & Sudan & DD \\
\hline Muridae & Haeromys margarettae & Oriental & rainforest & Malaysia & DD \\
\hline Muridae & Hydromys neobritannicus & Australian & wetlands & $\begin{array}{l}\text { Papua New } \\
\text { Guinea }\end{array}$ & DD \\
\hline Muridae & Lamottemys okuensis & Afrotropical & rainforest & Cameroon & EN \\
\hline Muridae & Leimacomys buettneri & Afrotropical & rainforest & Togo & DD \\
\hline Muridae & Lemniscomys hoogstraali & Afrotropical & rainforest & Sudan & DD \\
\hline Muridae & Lemniscomys mittendorfi & Afrotropical & rainforest & Cameroon & VU \\
\hline Muridae & Lemniscomys roseveari & Afrotropical & rainforest & Zambia & DD \\
\hline Muridae & Lophuromys eisentrauti & Afrotropical & rainforest & Cameroon & EN \\
\hline Muridae & Melomys fulgens & Oriental & rainforest & Indonesia & DD \\
\hline Muridae & Melomys matambuai & Australian & rainforest & $\begin{array}{l}\text { Papua New } \\
\text { Guinea }\end{array}$ & EN \\
\hline Muridae & Melomys paveli & Oriental & rainforest & Indonesia & DD \\
\hline Muridae & Microhydromys musseri & Australian & rainforest & $\begin{array}{l}\text { Papua New } \\
\text { Guinea }\end{array}$ & DD \\
\hline Muridae & Mylomys rex & Afrotropical & unknown & Ethiopia & DD \\
\hline Muridae & Nilopegamys plumbeus & Afrotropical & wetlands & Ethiopia & CR \\
\hline Muridae & Palawanomys furvus & Oriental & rainforest & Philippines & DD \\
\hline Muridae & Paramelomys steini & Australian & rainforest & $\begin{array}{l}\text { Papua New } \\
\text { Guinea }\end{array}$ & DD \\
\hline Muridae & Pithecheir melanurus & Oriental & rainforest & Indonesia & VU \\
\hline Muridae & Pithecheirops otion & Oriental & rainforest & Malaysia & $\mathrm{DD}$ \\
\hline Muridae & Praomys minor & Afrotropical & rainforest & Congo RD & $\mathrm{DD}$ \\
\hline Muridae & Praomys mutoni & Afrotropical & rainforest & Congo RD & DD \\
\hline Muridae & Rattus arfakiensis & Australian & rainforest & $\begin{array}{l}\text { Papua New } \\
\text { Guinea }\end{array}$ & DD \\
\hline Muridae & Rattus blangorum & Oriental & rainforest & Indonesia & DD \\
\hline Muridae & Rattus enganus & Oriental & rainforest & Indonesia & $\mathrm{DD}$ \\
\hline Muridae & Rattus koopmani & Oriental & rainforest & Indonesia & DD \\
\hline Muridae & Rattus pelurus & Oriental & rainforest & Indonesia & DD \\
\hline Muridae & Rattus timorensis & Oriental & rainforest & Indonesia & DD \\
\hline Muridae & Solomys salamonis & Australian & rainforest & Solomon & DD \\
\hline Muridae & Sommeromys macrorhinos & Oriental & rainforest & Indonesia & DD \\
\hline Muridae & Stenocephalemys ruppi & Afrotropical & rainforest & Ethiopia & DD \\
\hline Muridae & Taeromys arcuatus & Oriental & rainforest & Indonesia & DD \\
\hline Muridae & Taeromys microbullatus & Oriental & rainforest & Indonesia & DD \\
\hline Muridae & Uromys imperator & Australian & rainforest & Solomon & $C R$ \\
\hline Muridae & Uromys boeadii & Australian & rainforest & $\begin{array}{l}\text { Papua New } \\
\text { Guinea }\end{array}$ & $C R$ \\
\hline Muridae & Uromys porculus & Australian & rainforest & Solomon & EX? \\
\hline Nesomyidae & Brachytarsomys villosa & Afrotropical & rainforest & Madagascar & EN \\
\hline Nesomyidae & Dendromus vernayi & Afrotropical & rainforest & Angola & DD \\
\hline Nesomyidae & Dendroprionomys rousseloti & Afrotropical & rainforest & Congo DR & DD \\
\hline Nesomyidae & Eliurus ellermani & Afrotropical & rainforest & Madagascar & DD \\
\hline Octodontidae & Aconaemys sagei & Neotropical & rainforest & Argentina & DD \\
\hline Octodontidae & Pipanacoctomys aureus & Neotropical & scrublands & Argentina & $C R$ \\
\hline
\end{tabular}




\begin{tabular}{|c|c|c|c|c|c|}
\hline Family & Species & Biogeographical region & Habitat & Country & IUCN status \\
\hline Octodontidae & Salinoctomys loschalchalerosorum & Neotropical & scrublands & Argentina & $\mathrm{CR}$ \\
\hline Sciuridae & Biswamoyopterus biswasi & Oriental & rainforest & India & $C R$ \\
\hline Sciuridae & Hylopetes winstoni & Oriental & rainforest & Indonesia & DD \\
\hline Sciuridae & Prosciurillus abstrusus & Oriental & rainforest & Indonesia & DD \\
\hline Sciuridae & Sundasciurus davensis & Oriental & rainforest & Philippines & DD \\
\hline \multicolumn{6}{|l|}{ Soricomorpha } \\
\hline Soricidae & Chodsigoa caovansunga & Oriental & rainforest & Vietnam & DD \\
\hline Soricidae & Chodsigoa parva & Oriental & grassland & China & DD \\
\hline Soricidae & Chodsigoa salenskii & Oriental & unknown & China & DD \\
\hline Soricidae & Congosorex polli & Afrotropical & rainforest & Congo DR & DD \\
\hline Soricidae & Crocidura dhofarensis & Palearctic & desert & Oman & DD \\
\hline Soricidae & Crocidura gracilipes & Afrotropical & unknown & Tanzania & DD \\
\hline Soricidae & Crocidura grandis & Oriental & rainforest & Philippines & DD \\
\hline Soricidae & Crocidura jenkinsi & Oriental & rainforest & India & $\mathrm{CR}$ \\
\hline Soricidae & Crocidura macowi & Afrotropical & grassland & Kenya & DD \\
\hline Soricidae & Crocidura musseri & Oriental & rainforest & Indonesia & DD \\
\hline Soricidae & Crocidura orii & Oriental & $\begin{array}{l}\text { temperate } \\
\text { forest }\end{array}$ & Japan & EN \\
\hline Soricidae & Crocidura polia & Afrotropical & rainforest & Congo DR & DD \\
\hline Soricidae & Crocidura ultima & Afrotropical & rainforest & Kenya & DD \\
\hline Soricidae & Cryptotis nelsoni & Neotropical & rainforest & Mexico & DD \\
\hline Soricidae & Myosorex rumpii & Afrotropical & rainforest & Cameroon & EN \\
\hline Soricidae & Myosorex schalleri & Afrotropical & rainforest & Congo DR & DD \\
\hline Soricidae & Paracrocidura graueri & Afrotropical & rainforest & Congo DR & DD \\
\hline Soricidae & Suncus ater & Oriental & rainforest & Malaysia & DD \\
\hline Talpidae & Mogera uchidai & Oriental & grassland & Japan & DD \\
\hline
\end{tabular}

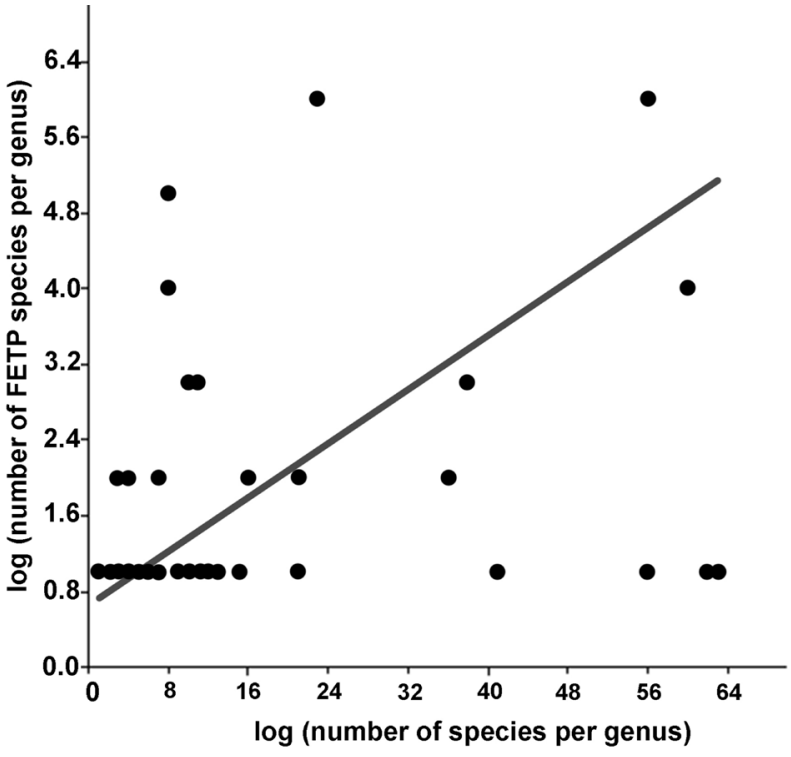

Figure 1. Correlation between number of species per genus and number of FETP species in each genus. For the statistical details, see the text.

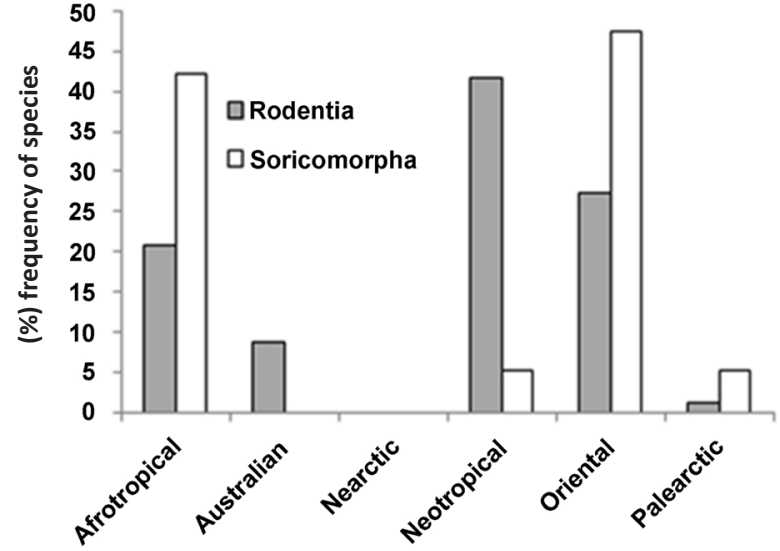

Biogeographic region

Figure 2. Percent of occurrence of FETP species of Rodentia and Soricomorpha, by biogeographical region. Percentages are calculated on the total number of species included in our analysis, and not on the total number of species of the two orders worldwide. 


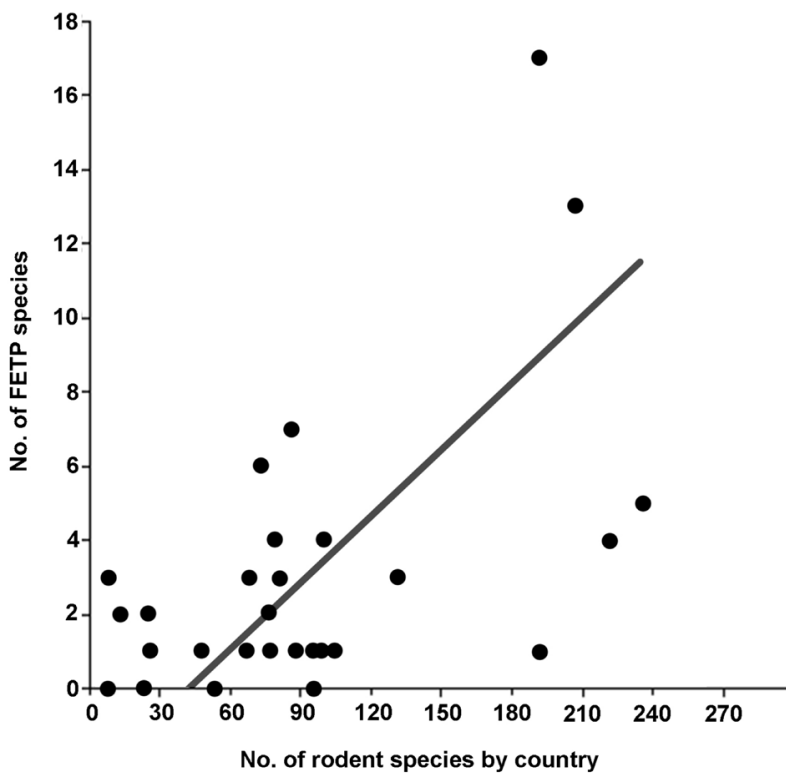

Figure 3. Relationships between rodent species richness per country and number of FETP species. For the statistical details, see the text.

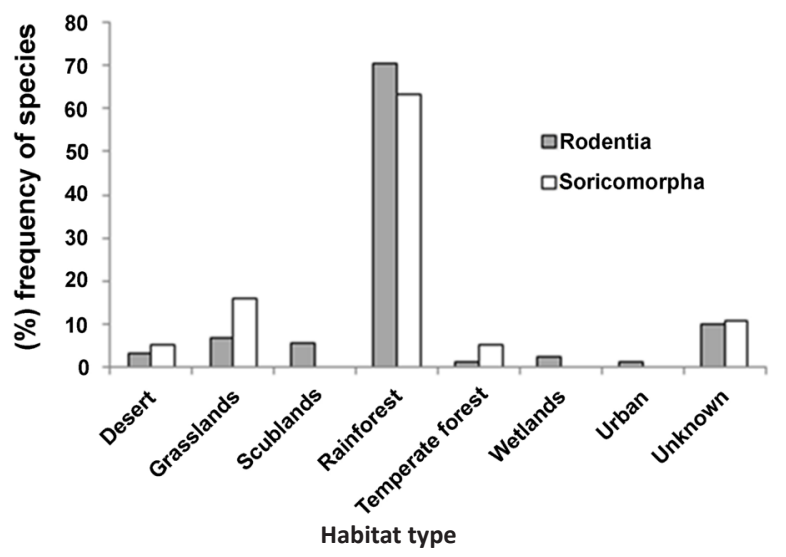

Figure 4. Percent of occurrence of the species of Rodentia and Soricomorpha known from just the type locality, with few individuals, by habitat type.

In terms of habitat type, the FETP species of rodents and soricomorphs showed similar patterns, with most species being found in rainforest (Fig. 4).

In terms of IUCN Red List Status, the great majority of FETP species were Data Deficient (DD) in both Rodentia (71.4\%, total $n=91$ ) and Soricomorpha (84.2\%, total $n=19)$. Critically Endangered (CR) species accounted for $16.5 \%$ of Rodentia and $5.3 \%$ of Soricomorpha, Endangered (EN) for, respectively, $6.6 \%$ and $10.5 \%$, Vulnerable (VU) for $3.3 \%$ and $0 \%$. Surprisingly, there was also a case of a Least Concern (LC) species in Rodentia (Archboldomys musseri). Based on the frequencies of species belonging
Table 2. List of FETP species of Rodentia and Soricomorpha, by country of origin. Blank space would indicate countries where soricomorphs do not occur because of biogeographic reasons.

\begin{tabular}{|c|c|c|}
\hline Country & No. of rodents & No. of soricomorphs \\
\hline Angola & 1 & 0 \\
\hline Cameroon & 3 & 1 \\
\hline Congo RD & 3 & 4 \\
\hline Ethiopia & 3 & 0 \\
\hline Kenya & 0 & 2 \\
\hline Libya & 1 & 0 \\
\hline Madagascar & 2 & \\
\hline Sudan & 4 & 0 \\
\hline Tanzania & 0 & 1 \\
\hline Togo & 1 & 0 \\
\hline Zambia & 1 & 0 \\
\hline Papua New Guinea & 6 & 0 \\
\hline Solomon Islands & 3 & 0 \\
\hline Argentina & 17 & \\
\hline Bolivia & 4 & \\
\hline Brazil & 4 & \\
\hline Colombia & 1 & \\
\hline Cuba & 2 & \\
\hline Equador & 1 & \\
\hline Guatemala & 1 & 0 \\
\hline Mexico & 5 & 1 \\
\hline Peru & 3 & \\
\hline China & 1 & 2 \\
\hline India & 1 & 1 \\
\hline Indonesia & 13 & 1 \\
\hline Japan & 0 & 2 \\
\hline Malaysia & 2 & 1 \\
\hline Philippines & 7 & 1 \\
\hline Vietnam & 0 & 1 \\
\hline Iran & 1 & 0 \\
\hline Oman & 0 & 1 \\
\hline Total & 91 & 19 \\
\hline
\end{tabular}

to the various IUCN Red List categories, there was a statistically significant difference between Rodentia and Soricomorpha $\left(\chi^{2}=14.25, d f=5, P=0.014\right)$, with a statistically higher frequency of CR species in rodents. In Rodentia, the majority of CR species $(n=15)$ came from the Neotropical region (60\%), whereas there was only a single CR species in Soricomorpha, coming from India. Overall, pooling $\mathrm{CR}, \mathrm{EN}$, and $\mathrm{VU}$, it resulted that most of the recorded rodents came from the Neotropical region 
(62.5\%, $n=24)$, followed by Afrotropical species (20.8\%).

The monotypic genera known from just the type locality were 11 (all rodents, i.e., Gliridae: Chaetocauda; Muridae: Lamottemys, Leimacomys, Nilopegamys, Palawanomys, Pithecheirops, Sommeromys; Nesomyidae: Dendroprionomys; Octodontidae: Pipanacoctomys, Salinoctomys; Echimyidae: Santamartamys), with four being Oriental, four Afrotropical, and three Neotropical genera. Concerning the monotypic genera, three are classified as $C R, 1 \mathrm{EN}$, and 7 DD.

\section{DISCUSSION}

Our study showed that a relatively high number of Rodentia (4\%) and Soricomorpha (4.4\%) species are FETP. The Neotropical region housed few soricomorphs and many rodents, most likely because the former are not found in South America and only a few live in central America (Churchfield 1990). Other important regions for both rodents and soricomorphs were the Oriental and Afrotropical regions, which also represent the regions with most speciose groups (Churchfield 1990; Ghazoul \& Sheil 2010). Rainforests emerged as the most important habitat type for both groups in terms of FETP species, which may be due to (i) the relative inaccessibility of wide rainforest zones in the tropics (Lewis \& Berry 2012), and also (ii) overall species richness is higher in this habitat type compared to other habitats (e.g., Ghazoul \& Sheil 2010). However, the pattern of occurrence of FETP species may be substantially influenced by possible biases in research efforts in individual geographic areas as well as by current attractiveness of individual taxonomic groups (e.g., dormice and squirrels vs. mice and rats).

Surprisingly, there is a lack of homogeneity in terms of IUCN Red List category (ranging from LC to CR) for FETP species, with the majority being listed as DD. We think that this results from the heterogeneity of assessors and their assumption that when a rodent species is extremely rare it is due to suboptimal research efforts. For instance, the Togo mouse Leimacomys buettneri, albeit (i) is known from just two specimens dating back to 1890 , and (ii) obtained from a relatively well explored area (Bismarckburg, Adéle area in southwestern Togo), is listed as DD despite it is presumed to be extinct by several authorities (e.g., Schlitter 1999). Therefore, we would urge the IUCN authorities to revise all FETP species and give them precautionary CR status, at least when a reasonable time-span (for instance, we may tentatively suggest $>25$ years) has passed since the last records. Currently, $15.8 \%$ of rodent species worldwide are DD, and application of machine-learning models to DD species predicted that several DD species should be instead considered to be threatened (Bland et al. 2015). Similarly, Howard \& Bickford (2014) showed that DD amphibian species are likely to be more threatened with extinction than their fully assessed counterparts, with some regions (in the Neotropical, Afrotropical and Oriental biogeographic regions) being particularly at risk due to lack of species knowledge and higher extinction risk than currently recognized. The field effort devoted to study a given FETP species is certainly also important in determining its real status, but this variable is difficult to quantify.

In our view, a precautionary re-assessment as CR is especially due to monotypic genera, given that their loss would mean the extinction of a full evolutionary lineage instead of a single species within a lineage. Our plea is urgently needed because, till a FETP species is listed as $\mathrm{DD}$, there will be virtually no way to get funds for exploring their true status, as nearly all the conservation grant sources available tend to focus on presently threatened species, i.e. those that are already listed as CR, EN or VU. Therefore, we suggest to change the paragraph 8.1 of the IUCN Red List guidelines, where it is recommended that '...if a taxon is only known from its type locality and there is no information on its current status or possible threats, the taxon should be listed as DD. If there are no plausible threats, and the area is relatively well known, Least Concern is appropriate, unless criterion A, $B$ or $C$ is met. If people have searched for the taxon, both at the type locality and at a reasonable number of other potential localities, and no more than 50 mature individuals are estimated, then the taxon would be listed as 'Critically Endangered'.

\section{REFERENCES}

Amori, G.\&S. Gippoliti(2000). What do mammalogists want to save? Ten years of mammalian conservation biology. Biodiversity Conservation 9: 785-793; http://dx.doi.org/10.1023/A:1008971823774

Amori, G., F. Chiozza, C. Rondinini \& L. Luiselli (2011a). Country-based patterns of total species richness, endemicity, and threatened species richness in African rodents and insectivores. Biodiversity Conservation 20: 1225-1237; http://dx.doi.org/10.1007/s10531011-0024-1

Amori, G., S. Gippoliti \& L. Luiselli (2011b). Do biodiversity hotspots match with rodent conservation hotspots? Biodiversity Conservation 20(14): 3693-3700; http://dx.doi.org/10.1007/s10531-011-0131-z

Bland, L.M., B. Collen, C.D.L. Orme \& J. Bielby (2015). Predicting the conservation status of data-deficient species. Conservation Biology 29: 250-259; http://dx.doi.org/10.1111/cobi.12372

Carpaneto, G.M., A. Mazziotta, R. Pittino \& L. Luiselli (2011). Exploring 
co-extinction correlates: the effects of habitat, biogeography and anthropogenic factors on ground squirrels-dung beetles associations. Biodiversity Conservation 20(13): 3059-3076; http:// dx.doi.org/10.1007/s10531-011-0162-5

Churchfield, S. (1990). The Natural History of Shrews. Christopher Helm, New York, NY.

Gippoliti, S. \& G. Amori (2011). A new species of mole-rat (Rodentia, Bathyergidae) from the Horn of Africa. Zootaxa 2918: 39-46.

Gaston, K.J. (1994). Rarity. Springer, Berlin.

Ghazoul, J. \& D. Sheil (2010). Tropical Rain Forest Ecology, Diversity, and Conservation. Oxford University Press, 536pp.

Golley, F.B., L. Ryszkowski \& J.T. Sokur (1975). The role of mammals in temperate forest, grasslands and coltivated fields, pp. 223-241. In: Golley F.B., K. Petrusewicz, L. Ryszkoski (eds.). Small Mammals: Their Productivity and Population Dynamics. Cambrige University.

Hafner, D.J., E. Yensen \& K.L. Gordon Jr. (1998). North American Rodents. Status survey and conservation Action Plan. IUCN/SSC Rodent Specialist Group. IUCN Gland, Switzerland and Cambridge UK, 171pp.

Howard, S.D. \& D. Bickford (2014). Amphibians over the edge: silent extinction risk of Data Deficient species. Diversity and Distributions 2014: 1-10; http://dx.doi.org/10.1111/ddi.12218
Lewis, L.A. \& L. Berry (2012). African environments and resources. Routledge, New York, 404pp.

McCain, C.M., R.M. Timm \& M. Weksler (2007). Redescription of the enigmatic Long-tailed Rat Sigmodontomys aphrastus (Cricetidae: Sigmodontinae) with comments on taxonomy and natural history. Proceedings of the Biological Society of Washington 120: 117-136.

Nowak, R.M. (1999). Walkers's Mammals of The World. Sixth Edition. John Hopkins University Press, Baltimore, 2015pp.

Řeháková, M., V. Řehák \& W.L.R. Oliver (2015). Rediscovery of the Dinagat Bushy-tailed Cloud Rat Crateromys australis (Musser, Heaney \& Rabor, 1985) (Mammalia: Rodentia: Muridae) from Dinagat Island, Philippines. Journal of Threatened Taxa 7(8): 74287435; http://dx.doi.org/10.11609/JoTT.04226.7428-35

Schlitter, D.A. (1999). African rodents of special concern: a preliminary assessment, pp. 33-39. In: Lidicker, W.Z. Jr. (ed.). Rodents - A World Survey of Species of Conservation Concern. Occasional papers of IUCN/SSC.

Wilson, D.E. \& D.R. Reeder (2005). Mammal Species of the World: A Taxonomic and Geographic Reference - $3^{\text {rd }}$ Edition. John Hopkins University Press, Baltimore, 2142pp. 